Résumés des conférences et travaux

\title{
Inscriptions grecques inédites dialectales et historiques
}

\section{Klaus Hallof}

\section{(2) OpenEdition}

\section{Journals}

Édition électronique

URL : https://journals.openedition.org/ashp/3596

DOI : 10.4000/ashp.3596

ISSN : 1969-6310

Éditeur

Publications de l'École Pratique des Hautes Études

\section{Édition imprimée}

Date de publication : 1 septembre 2020

Pagination : 102-103

ISSN : 0766-0677

\section{Référence électronique}

Klaus Hallof, «Inscriptions grecques inédites dialectales et historiques », Annuaire de l'École pratique des hautes études (EPHE), Section des sciences historiques et philologiques [En ligne], 151 | 2020, mis en ligne le 09 juillet 2020, consulté le 06 juillet 2021. URL : http://journals.openedition.org/ashp/3596 ; DOI : https://doi.org/10.4000/ashp.3596 


\title{
INSCRIPTIONS GRECQUES INÉDITES DIALECTALES ET HISTORIQUES
}

\author{
Conférences de M. Klaus Hallof, \\ Leiter der Arbeitsstelle Inscriptiones Graecae an der Berlin- \\ Brandenburgischen Akademie der Wissenschaften, \\ directeur d'études invité
}

\section{Inscriptions d'Olympie d'époque classique}

\section{Jugement de trois juges de Pellana pour les Ledriniens}

Une tablette de bronze découverte à Olympie en 2011, datant du début du $\mathrm{v}^{\mathrm{e}} \mathrm{s}$. av. J.-C., contient une sentence de justice émanant de trois juges de Pellana destinée à la cité de Lédrinoi, apparemment pour mettre fin à des troubles intérieurs (stasis). Le jugement stipule une réduction temporaire des droits civiques (atimia) pour les membres d'une hétairie, qui porte le nom remarquable de Kilikikoi. En cas de non-respect de la sentence sont prévues de sévères sanctions. Le jugement est assorti d'une interdiction, de clauses de mise en application et de l'exclusion de la responsabilité des juges. D'autre part, le texte contient des éléments du dialecte éléen ancien et du dialecte achéen ancien, jusqu'ici peu attesté, et présente cinq hapax legomena remarquables. Cette inscription sera publiée par K. Hallof et S. Minon.

\section{2. Épigramme en l'honneur de Deinosthénès de Lacédémone}

Découverte il y a plusieurs décennies en remploi dans une construction tardive, une base de marbre de la $2^{\mathrm{e}}$ moitié du IV ${ }^{\mathrm{e}} \mathrm{s}$. av. J.-C. porte une inscription qui n'a pu être déchiffrée que tout récemment. Elle révèle le rôle que joua à Sparte, sa patrie,

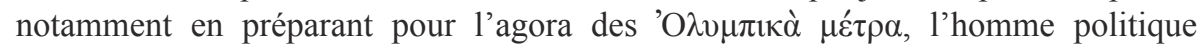
Deinosthénès. Or, celui-ci était déjà connu comme vainqueur à Olympie à la course du stade chez les hommes par Pausanias VI 16, 6, qui cite l'inscription d'Olympie l'honorant, laquelle avait été trouvée en deux fragments à Olympie en 1880 et 1881 (I. Olympia 171). Ces sources anciennement connues doivent désormais être réétudiées à la lumière de la nouvelle inscription. Ce dossier a maintenant été publié dans Chiron, 49 (2019), p. 173-186.

\section{Inscriptions de Cos des époques hellénistique et augustéenne}

\section{Six décrets d'asylie et deux nouvelles lettres royales}

En 242 av. J.-C. les Coens avaient envoyé des ambassades sacrées (theoriai) demandant que soient reconnus le concours par eux organisé en l'honneur d'Asklepios, la trêve durant sa célébration (ekecheiria) et l'asylie du sanctuaire d'Asclépios. On connaissait jusqu'à présent à peu près 40 décrets et 7 lettres royales composant ce dossier (IG XII 4, 207-234). Or, une stèle découverte en 2017 révèle plusieurs 
décrets, dont trois complets, de cités répondant à la demande d'asylie de Cos : y figurent les cités d'Aigai, Beroia et Thessalonique, ainsi que le décret de Temnos en dialecte éolien. De façon tout à fait inattendue, se trouvent en outre entre les décrets de cités deux lettres de souverains hellénistiques : une lettre de la reine Laodicè et une seconde lettre du roi de Bithynie Zigelas (= Ziaëlas).

\section{Catalogue de souscripteurs appelés philokaisares}

Découverte en 2012 sur l'Agora de Cos, une stèle haute de 3,70 m et large de $1,50 \mathrm{~m}$ porte la plus longue inscription de l'île et même de toute l'Égée orientale : c'est la liste, sur 301 lignes, de souscripteurs, qui pour la plupart font également des versements au nom de leurs parents. Sont ainsi connus presque 1000 personnes, où l'onomastique permet de reconnaître des Grecs, des Romains et des Grecs devenus citoyens romains. Le préambule mutilé donne la date, à l'époque d'Auguste, et la destination des versements, qui se montent seulement à environ 14000 deniers. Il est remarquable qu'environ un tiers des souscripteurs est distingué par le titre honori-

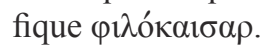

